\title{
Role of Integrin Expression in Adenovirus-Mediated Gene Delivery to the Intestinal Epithelium
}

\author{
MARIA A. CROYLE, ${ }^{1,4}$ ELKE WALTER, ${ }^{2}$ SONIA JANICH, ${ }^{3}$ BLAKE J. ROESSLER,,${ }^{1,3}$ and \\ GORDON L. AMIDON ${ }^{1}$
}

\begin{abstract}
Adenoviral vectors are being developed for oral delivery of therapeutic genes to the intestine. Initial studies in the rat using mucolytics and direct application of adenovirus encoded with the interleukin-1 receptor antagonist gene to the jejunum produced limited gene expression. The goal of this study was to determine the role of integrins in adenovirus-mediated gene delivery to the intestinal epithelium. Integrins are involved in cellular differentiation and tight junction formation and mediate adenoviral internalization. Results from Caco-2 and IEC-18 cells suggest that, as enterocytes differentiate, cell-surface integrin expression decreases. Pretreatment of Caco-2 cells with RGD peptides reduced adenoviral transduction efficiency by $80 \%$ in undifferentiated cells and $20 \%$ in differentiated cells. Both differentiated and undifferentiated IEC-18 cells showed a $70 \%$ drop in transduction when pretreated with the peptide. Infection inhibition studies with monoclonal antibodies further suggest that $\alpha_{v} \beta_{3}$ and $\alpha_{6} \beta_{1}$ integrins play significant roles in adenoviral internalization in the intestine. Expression of integrins in cell culture models of the intestine correlated with in vivo expression in intestinal segments. These results indicate that the ileum is a prime target for efficient adenovirus-mediated gene transfer in the rat. To enhance transduction in differentiated enterocytes (probable targets for oral gene delivery), Caco-2 cells were treated with interleukin-1 $\beta$ (a cytokine known to increase integrin expression) prior to administration of the virus. Transduction efficiency increased four-fold.
\end{abstract}

\section{OVERVIEW SUMMARY}

Previous studies of adenovirus-mediated gene transfer of the interleukin-1 receptor antagonist protein to rat jejunum have produced limited gene expression. In the present study, we have shown that integrins play a significant role in efficient adenoviral infection of the intestinal epithelium. As enterocytes differentiate, integrin expression decreases. This coincides with significant reduction in adenoviral transduction efficiency. Results from two in vitro models of the intestinal epithelium (Caco-2 and IEC-18 cells) show that $\alpha_{v} \beta_{3}$ integrins have the most influence on adenoviral internalization. Results from screening of rat intestinal segments for expression of the $\alpha_{v} \beta_{5}$ integrin suggest that, based on integrin expression, the ileum is a prime target for efficient adenovirus-mediated gene transfer. We have also found that administration of immunomodulating agents and inflammatory disease states provide a favorable environment for efficient internalization of adenoviral vectors due to up-regulation of integrin receptors.

\section{INTRODUCTION}

$\mathbf{T}$ HE INTESTINAL EPITHELIUM is considered to be an attractive site for somatic gene therapy for many reasons. One of the most compelling is its ease of access via the lumenal route, which would allow direct in vivo gene transfer by oral administration or standard endoscopic approaches (Sandberg et al., 1994). The intestinal epithelium also has a large tissue mass and contains stem cells with known locations in the crypts of Lieberkühn (Chang et al., 1994). Development of cystic fibro-

\footnotetext{
${ }^{1}$ College of Pharmacy, The University of Michigan, Ann Arbor, MI 48109-1065.

2Department Pharmazie, ETH Zurich, CH-8057 Zurich, Switzerland.

${ }^{3}$ Department of Internal Medicine, Division of Rheumatology, University of Michigan Medical Center, Ann Arbor, MI 48109.

${ }^{4}$ Present address: Institute of Human Gene Therapy, Department of Molecular and Cellular Engineering, University of Pennsylvania, Philadelphia, PA 19104.
} 
sis (CF) mouse models with early mortality due to intestinal obstruction has emphasized the importance of the intestine as a site for gene transfer (Colledge et al., 1992; O'Neal et al., 1993).

Aside from CF, other genetic disorders that affect the intestinal epithelium such as familial adenomatous polyposis (FAP) (Westbrook et al., 1994) and many cases of colon cancer (Thomas, 1991) could be treated or prevented with site-directed gene transfer. The intestine could also be used as an alternative target for the treatment of many metabolic and nutritional defects, especially for functions that occur in the liver, such as urea cycle disorders and phenylketonuria. Some transgenic studies have shown that the intestinal epithelium is capable of secreting proteins into the blood stream (Sweetser et al., 1988). Thus, the intestine could also serve as an important target for diseases involving the deficiency of proteins secreted into the blood such as hormones and clotting factors (Ledley, 1992).

Recently, utilization of replication-deficient mammalian viruses as vectors for gene delivery and as potential vaccine carriers has received increasing attention. Adenoviruses seem particularly suited for such purposes because infection with these replication-incompetent vectors allow for the production of transgenic proteins without adversely affecting the host cell (Smythe et al., 1995). Deletions in the E1 and E3 regions of the viral genome allow for insertion of about $8 \mathrm{~kb}$ of foreign DNA without affecting the viability of the virus. Replicationdefective forms of human adenoviruses have been used to deliver foreign genes into diverse cell types, including liver, muscle, nerve, and airway epithelial cells (Engelhardt et al., 1993; Roessler et al., 1993; Ragot et al., 1994; Kozarsky et al., 1996). The success of the adenovirus as a gene delivery vector is based in part on its highly efficient mode of cell entry and its lack of requirement for host cell replication. To date, there have been few reports of successful adenovirus-mediated gene delivery to the intestinal epithelium.

Significant progress has been made in elucidating the steps involved in adenoviral entry, which involves interaction of viral particles with two separate cell receptors. Initial binding of the adenovirus to the cell surface is mediated by the fiber capsid protein (Defer et al., 1990; Wickham et al., 1994). Recently, the CAR (coxsackievirus and adenovirus receptor) protein has been identified as a functional receptor for adenovirus binding to HeLa cells (Bergelson et al., 1997). The distribution of this receptor in other cell types and tissues is currently being investigated and CAR sequences are identical to genomic and EST clones that map to human chromosome 21, an area where the adenovirus 2 receptor has been located (Mayr and Freimuth, 1997; Tomko and Freimunt, 1997).

The subsequent event of virus entry into cells occurs via internalization into clathrin-coated vesicles, which is mediated by binding of the viral penton base to $\alpha_{\mathrm{v}}$ integrins. Adenovirus interaction with $\alpha_{\mathrm{v}}$ integrins is mediated by an arginine-glycineaspartic acid (RGD) sequence predicted to be located at the apex of a $10 \AA(1 \mathrm{~nm})$ protrusion on the penton base protein (Neumann et al,, 1988; Stewart et al., 1995). The RGD sequence motif is conserved in multiple adenoviral serotypes, indicating that these viruses use a common pathway for entry into host cells (Bai et al., 1993). Several studies (Wickham et al., 1994; Goldman and Wilson, 1995; Huang et al., 1995, 1996) have shown that adenoviral infection can be inhibited by the penton base, RGD peptides, and monoclonal antibodies against $\alpha_{\mathrm{v}} \beta_{5}$ and $\alpha_{\mathrm{v}} \beta_{3}$ integrins. These results suggest that interaction of the penton base with $\alpha_{\mathrm{v}}$ integrins fosters viral internalization.

We are interested in delivering anti-inflammatory proteins to the intestine for the treatment of inflammatory bowel disease by oral administration of adenoviral vectors. Initial in vivo studies in the rat involving the use of mucolytics and direct application of adenovirus encoded with the interleukin-1 (IL-1) receptor antagonist gene to the jejunum have produced limited and transient gene expression in the intestinal epithelium (unpublished data). We have chosen two cell lines-Caco-2, a human transformed cell line considered to be a standard model of the human intestinal epithelium (Hidalgo et al., 1989), to predict transduction efficiency in humans, and IEC-18, a primary cell line originating from the small intestinal epithelium of the rat (Quaroni et al., 1979) - to assess selection of an animal model for oral gene delivery. In vitro data from these cell lines have provided us with a possible reason for the limited gene expression we have observed (Walter et al., 1997a; Fig. 1A).

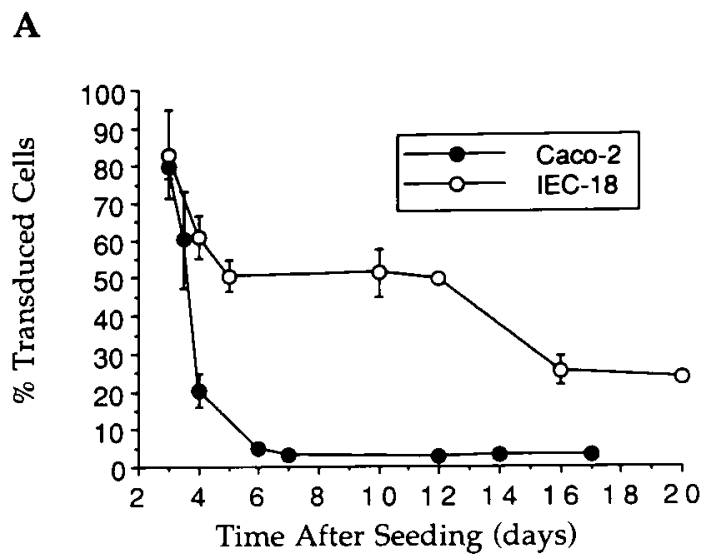

B

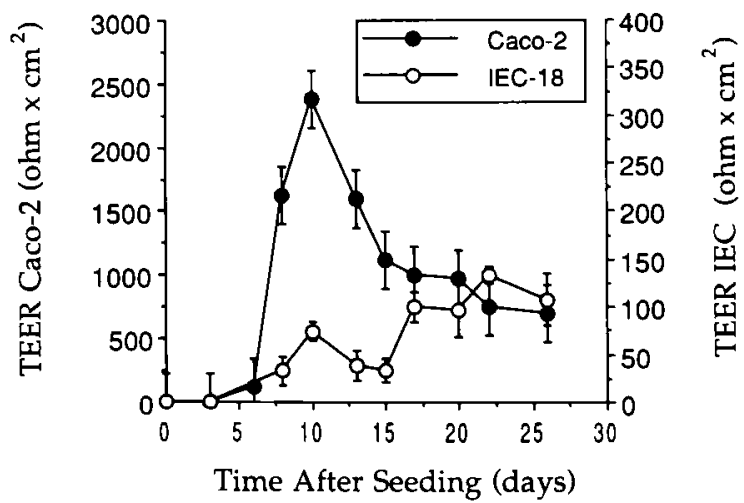

FIG. 1. A. Transduction efficiency of AdRSVntlacZ in Caco2 and IEC-18 cells is affected by age of cells at time infection. Percent transduction is the number of transduced cells relative to the total cellular population. B. TEER values for Caco- 2 and IEC-18 monolayers indicate when a differentiated state has been reached. Error bars represent the standard deviation of the data. 
As these cells remain in culture, their ability to be transduced by adenovirus type 5 significantly decreases. The drop in transduction appears to correlate with the time it takes for these cell lines to differentiate, indicated by one marker of differentiation development of transepithelial electrical resistance (TEER) readings (Audus et al., 1990; Artursson, 1991; Fig. 1B). In this report, we have looked at one of the steps of adenoviral infection: internalization of the virus. We have determined that integrin expression changes over time as enterocytes remain in culture, identified which integrins play significant roles in adenoviral internalization in the intestine, and screened various segments of rat intestinal tissue for integrin expression. This information has helped us identify a possible cause for transient adenovirus-mediated gene expression in intestinal tissues and assisted us in the development and selection of animal models for oral gene therapies.

\section{MATERIALS AND METHODS}

\section{Materials}

Tissue culture reagents were obtained from GIBCO-BRL (Grand Island, NY) and tissue culture materials were from Becton Dickinson (Franklin Lakes, NJ) and Coming (Corning, NY). Monoclonal antibodies MAB 1961 (against $\alpha_{\mathrm{v}} \beta_{3}$ integrins), MAB 1976 (against $\alpha_{\mathrm{v}} \beta_{5}$ integrins), and MAB 1410 (against $\alpha_{6} \beta_{1}$ integrins) were purchased from Chemicon International (Temecula, CA). The GRGDSP and GRGESP RGD peptides were purchased from GIBCO-BRL (Rockville, MD). Recombinant human $\mathrm{IL}-1 \beta$ ( $>[97 \%$ purity) was purchased from $\mathrm{R} \&$ D Systems (Minneapolis, MN).

\section{Cell culture}

Caco-2 cells (ATCC HTB37) of passages 45-60 were maintained in Dulbecco's modified Eagle's medium (DMEM) containing high glucose (4.5 grams/liter) and supplemented with $10 \%$ heat-inactivated fetal bovine serum (FBS), $1 \%$ nonessential amino acids, $1 \mathrm{mM}$ sodium pyruvate, $1 \%$ L-glutamine, and penicillin $(100 \mathrm{U} / \mathrm{ml}) / \mathrm{streptomycin}(100 \mu \mathrm{g} / \mathrm{ml})$.

IEC-18 cells (ATCC 1589) of passages 12-17 were maintained in DMEM containing high glucose ( 4.5 grams/liter) and supplemented with $10 \%$ heat-inactivated FBS, $0.1 \mathrm{U} / \mathrm{ml}$ insulin, and penicillin $(100 \mathrm{U} / \mathrm{ml}) /$ streptomycin $(100 \mu \mathrm{g} / \mathrm{ml})$. Medium was changed every other day for each of the intestinal cell lines. All cells were grown at $37^{\circ} \mathrm{C}$ in an atmosphere of $5 \% \mathrm{CO}_{2}$ and $90 \%$ relative humidity.

\section{TEER measurements}

Both Caco-2 and IEC-18 cells were seeded at a density of 100,000 cells/well on porous polycarbonate cell culture inserts with a pore size of $0.4 \mu \mathrm{m}$ and a surface area of $4.7 \mathrm{~cm}^{2}$ in clusters of six wells (Costar Transwell, Cambridge, MA). Medium was changed in apical and basolateral chambers every other day. TEER measurements were taken by an epithelial voltohmeter with a special "chopstick" electrode designed for this purpose (World Precision Instruments, Sarasota, FL). TEER values were determined by subtracting measured TEER values from the intrinsic resistance of the membrane. Data is reported as measured resistance $\times$ surface area of membrane.

\section{Preparation of adenovirus}

A replication-deficient strain of human adenovirus serotype 5 expressing either a nuclearly targeted Escherichia coli $\beta$ galactosidase ( $\beta$-Gal) marker gene or the jellyfish green fluorescent protein (GFP) under the control of a Rous sarcoma virus promoter was amplified in the 293 cell line using a modification of established methods (Graham and van der Eb, 1973). Virus was purified from cell lysates by banding twice on $\mathrm{CsCl}$ gradients followed by desalting on a Sephadex G-50 column (Sigma Biochemicals, St. Louis, MO) in phosphate-buffered saline (PBS; Sigma). The concentration of the virus was determined by UV spectrophotometric analysis at $260 \mathrm{~nm}$. All experiments were performed with freshly purified adenovirus stock. Lac-forming assays were performed prior to experimentation.

\section{Limiting dilution/Lac-forming assays}

The term lac-forming unit (lfu) describes the amount of virus present in a preparation that can infect cells and induce expression of the $E$. coli $\beta$-Gal gene at levels sufficient for visual identification of blue reaction product resulting from enzymatic cleavage of the chromogenic substrate X-Gal. Lac-forming units were determined according to the following procedure. Desalted fractions of virus were serially diluted in DMEM supplemented with $2 \%$ heat-inactivated FBS and antibiotics. The complete medium was removed from the wells of six-well dishes that had been sealed with $1.5 \times 10^{5}$ cells/well $48 \mathrm{hr}$ earlier and $0.25 \mathrm{ml}$ of the appropriate dilution was added to confluent 293 cells. After incubation for $2 \mathrm{hr}$ at $37^{\circ} \mathrm{C}, 2.5 \mathrm{ml}$ of complete medium was added to each well and the infection was allowed to progress for $20 \mathrm{hr}$ at $37^{\circ} \mathrm{C}$. After $20 \mathrm{hr}$, cells were stained by the X-Gal protocol described below. Lac-forming units were calculted using the following formula:

$$
\mathrm{lfu} / \mathrm{ml}=z \times a \times d
$$

where $z=7,434$, a magnification constant; $a=$ the average number of blue lac ${ }^{+}$cells from duplicate samples; and $d=$ the diluton of the sample.

\section{Adenoviral infection inhibition studies}

Both Caco-2 and IEC-18 cells were seeded in six-well plates at a density of 100,000 cells/well for all infection studies. At 3 or 21 days after seeding, medium was removed and $0.25 \mathrm{ml}$ of a solution of DMEM, $2 \%$ FBS, $25 \mathrm{~m} M$ HEPES pH 7.4 containing either $1 \mu \mathrm{g} / \mu \mathrm{l}$ of the desired monoclonal antibody or the specified concentration of RGD peptide was placed on the monolayers. The cells were incubated with the antibody or peptide solution for $2 \mathrm{hr}$ at $4^{\circ} \mathrm{C}$ to allow for binding. Dishes were gently rocked every $15 \mathrm{~min}$ to ensure adequate coating of the monolayer.

After $2 \mathrm{hr}$, the antibody or peptide solution was removed and a solution of DMEM, 2\% FBS, $25 \mathrm{~m} M$ HEPES containing 50 Ifu of AdRSVntlacZ was placed on the cell monolayers. The cells were incubated at $4^{\circ} \mathrm{C}$ for $1 \mathrm{hr}$ to allow for viral attachment. After this, the cells were placed at $37^{\circ} \mathrm{C}$ for an additional $30 \mathrm{~min}$ to allow for viral internalization. After this time, the viral solution was removed and the cells were washed twice with 
HEPES-buffered saline (HBS). Cells were then treated with trypsin (0.5 gram/liter) and EDTA (0.2 gram/liter) in Hank's buffered salt solution (HBSS) for 10-15 min to remove any virions that were not internalized. Cells that had detached were then replated on Falcon Primara six-well plates in their respective complete mediums. Forty-eight hours later, X-Gal stains were performed and the number of cells infected by the virus tabulated and compared to control samples that did not receive any treatment prior to infection.

\section{$X$-Gal staining}

Cells were washed with $10 \mathrm{~m} M$ PBS, fixed with $0.5 \%$ glutaraldehyde for $10 \mathrm{~min}$, and washed twice with PBS containing $1 \mathrm{~m} M \mathrm{MgCl}_{2}$. $\beta$-Gal activity was determined by incubation of infected cells with the substrate 5-bromo-4-chloro-3-indolyl- $\beta$ galactoside (X-Gal; GIBCO-BRL, Grand Island, NY) (Miller, 1972) for $4 \mathrm{hr}$ at $37^{\circ} \mathrm{C}$ in the dark. Staining medium was removed and blue-stained lac ${ }^{+}$cells were counted from a minimum of 20 microscope fields (approximately 480,000 cells).

\section{Immunohistochemical identification of integrins with fluorescence microscopy}

IEC-18 Cells: IEC-18 cells were seeded in two-chamber microscope slides (Supercell, Fisher Scientific) at a density of 300,000 and 100,000 cells/well, respectively. At both 3 and 21 days after seeding, immunohistochemical staining was done using a modification of established methods (Hrapchak, 1987). Cells were fixed with $200 \mu \mathrm{l}$ of cold $4 \%$ formalyn (EM Sciences, Fort Washington, PA) in PBS for $10 \mathrm{~min}$. After rinsing in PBS, the monolayers were blocked with a solution of $10 \%$ goat serum (Sigma Biochemicals, St. Louis, MO) in PBS for 20 min. After blocking, primary antibody was added at a concentration of $100 \mu \mathrm{g} / \mathrm{ml}$ in $10 \%$ goat serum and the monolayer incubated for $1 \mathrm{hr}$ at room temperature. Goat anti-mouse fluorescein isothiocyanate (FITC)-conjugated secondary antibody (Sigma Biosciences, St. Louis, MO) in $10 \%$ goat serum was added in a 1:200 dilution in the dark for an additional hour. After this time, the monolayers were rinsed with PBS, dipped in methanol (EM Sciences Fort Washington, PA), and then coverslips were placed on the slides. Citiflour (UKC Chem. Lab, Canterbury, UK) was placed dropwise on microscope slides to enhance fluorescence. Cells were photographed using a Nikon (Tokyo, Japan) Diaphot-TMD inverted microscope with a fluorescent attachment.

Rat Intestinal Tissue Sections: Intestinal tissue was removed from euthanized white Sprague-Dawley rats via a longitudinal incision in the abdominal area. Once specific areas of the intestine were identified, they were excised, profusely rinsed with PBS, split open longitudinally, and rapidly immersed in disposable peel-away molds containing O.C.T. Compound (Miles Diagnostics Ekhart, IN). Frozen molds were stored at $-80^{\circ} \mathrm{C}$ until cryo-sectioned. Sections were $8-10 \mu \mathrm{m}$ thick, placed on microscope slides, and stored at $-80^{\circ} \mathrm{C}$ until use. The immunohistochemical isolation of integrins on these tissues was similar to that described for Caco-2 and IEC-18 cells.

\section{Induction of enterocolitis in Sprague-Dawley rats}

Animal experiments were performed in accordance with in- stitutional guidelines and approved by the University Committee on Use and Care of Animals at the University of Michigan. Chronic intestinal inflammation was induced in adult female Lewis rats by subserosal injection of purified peptidoglycan-polysaccharides (PG-PS) complex from the cell wall of Streptococcus pyogenes (Zimmerman et al., 1993) as described previously (Sartor et al., 1985). In brief, rats were anesthetized and underwent laparotomy. A $12.5-\mu \mathrm{g}$ amount of purified PG-PS complex/gram of body weight in $0.05 \mathrm{ml}$ of pyrogen-free saline $\mathrm{pH}$ 7.2 was injected subserosally in seven standard locations in the ileal Peyer's patches, cecum, and ileal mesentery. Twenty-one days after injection, during the chronic phase of inflammation, rats were euthanized, colonic segments processed, and immunohistochemical analysis was performed as described previously.

\section{Preparation of intestinal loops for adenoviral infection}

A 3/4-inch midline incision was made in the anterior abdominal wall of anesthetized Sprague-Dawley rats. An appropriate segment of either the ileum or the jejunum was located and carefully brought to the surface of the cavity. A loop of approximately $7 \mathrm{~mm}$ in length was ligated loosely with fine surgical silk. Adenovirus encoded with the jellyfish GFP at a concentration of $2 \times 10^{12}$ particles $/ \mathrm{ml}$ was introduced into the proximal end of the loop using a 30-gauge needle affixed to a 1 -cc syringe. Each loop accommodated approximately $0.7 \mathrm{ml}$ of fluid to moderately distend the loop. Care was taken during the surgical procedure to provide for viability of the blood supply and to maintain normal peristalsis. Each loop remained outside the peritoneum for $2 \mathrm{hr}$ after which the ligation was released and the intact intestine returned to the abdominal cavity of the animal. The abdominal incision was stitched closed and the animal allowed to recover. Twenty-four hours after dosing, animals were euthanized. Treated intestinal segments were extracted, rinsed profusely with PBS, split open longitudinally, and rapidly immersed in disposable peel-away molds containing O. C. T. Compound (Miles Diagnostics Ekhart, IN). Frozen molds were stored at $-80^{\circ} \mathrm{C}$ until cryosectioned. Sections were 8-10 $\mu \mathrm{m}$ thick, and GFP expression was detected with a Nikon Diaphot-TMD inverted microscope with a fluorescent attachment.

\section{RESULTS}

\section{Effect of enterocyte differentiation on adenovirus-mediated gene delivery}

The Caco- 2 cell line, considered to be a standard model of the human intestinal epithelium, which has been shown to undergo spontaneous enterocytic differentiation in culture ( $\mathrm{Hi}$ dalgo et al., 1989; Yoshioka et al., 1991; Vachon and Beaulieu, 1992), was used to predict adenoviral transduction efficiency in humans. IEC-18 cells, originating from the small intestinal epithelium of the rat and also known to differentiate in culture (Quaroni et al., 1979; Ma et al., 1992) were used to assess selection of an appropriate animal model for oral gene delivery. To determine if enterocyte differentiation affects transduction efficiency of adenovirus type 5 , a fixed amount of virus was added to both cell lines at various times after initial seeding. When infected with a dose of 10 lfu of AdRSVntlacZ 3 days 
after seeding, $79.6 \%$ of the Caco- 2 cell population expressed the $E$. coli $\beta$-Gal marker gene (Fig. 1A). When the same dose of virus was added $12 \mathrm{hr}$ later, the gene was expressed in $60.2 \%$ of the cellular population. When infected 4 days after seeding, $20.4 \%$ of the population expressed the gene. When the cells were infected between 7 and 17 days after seeding, the transduction efficiency remained constant with approximately $3 \%$ of the population expressing the lac $Z$ gene. This drop in transduction efficiency appears to correlate with the time it takes the cells to reach a highly differentiated state as indicated by development of TEER readings (Grasset et al., 1984; Fig. 1B). At day 3 , there was no recordable resistance measurement and transduction efficiency was high. By day 6 , when extremely low levels of gene expression began, the TEER increased to $125 \mathrm{ohm} / \mathrm{cm}^{2}$, indicating that the differentiation process had begun.

When infected with a dose of 10 lfu virus 3 days after seeding, $82.9 \%$ of the IEC-18 cells expressed the lacZ gene (Fig. 1A). When infected 4 days after seeding, $60.9 \%$ of the cellular population expressed the gene. Between 5 and 10 days after seeding, the transduction efficiency remained constant with approximately $50 \%$ of the population consistently expressing the lacZ gene. Transduction efficiency underwent another drop to $25.2 \%$ and $23.4 \%$ of the cellular population expressing the gene at days 16 and 20, respectively. Even though the TEER values of IEC-18 cells were much lower than those of Caco-2 cells, they could still be used to assess when the monolayer reached a differentiated state. At day 3 , there was no recordable resistance measurement and transduction was high. At day 8 , the TEER began to rise to $33 \mathrm{ohm} / \mathrm{cm}^{2}$ and plateaued at 100 $\mathrm{ohm} / \mathrm{cm}^{2}$ between days 17 and 20 , indicating the development of a highly differentiated state (Fig. 1B). At this time, transduction marketed dropped.

\section{Effect of RGD peptide on transduction efficiency of the adenoviral vector}

To determine if $\alpha_{\mathrm{v}}$ integrins were present on both Caco-2 and IEC- 18 cells and to assess changes in integrin expression during the differentiation process, cells at early and late stages of differentiation were treated with varying concentrations of RGD peptides prior to addition of adenovirus. Distinct differences in blocking of adenoviral transduction efficiency were seen between undifferentiated and highly differentiated Caco2 cells (Fig. 2A). Highly differentiated cells, those infected with 50 lfu virus 21 days after seeding, demonstrated at $16.3 \%$ drop in transduction after pretreatment with $0.4 \mathrm{mM}$ RGD peptide compared to untreated cells. When $1.7 \mathrm{~m} M$ of RGD peptide was added to the cells, a $20.2 \%$ reduction in transduction efficiency was seen. This represents almost complete blockage of infection when compared to untreated cells due to inefficient transduction at this stage of differentiation and as higher concentrations of the peptide were added to the differentiated cells, inhibition of adenoviral infection remained constant at approximately $20 \%$.

In undifferentiated cells, transduction was reduced by $69.5 \%$ (a level similar to that of untreated, differentiated Caco-2 cells) after pretreatment with $0.4 \mathrm{~m} M$ of the peptide. As higher concentrations of RGD peptide were added to these cells, no further reduction in transduction was seen with $65 \%$ reduction re-
A

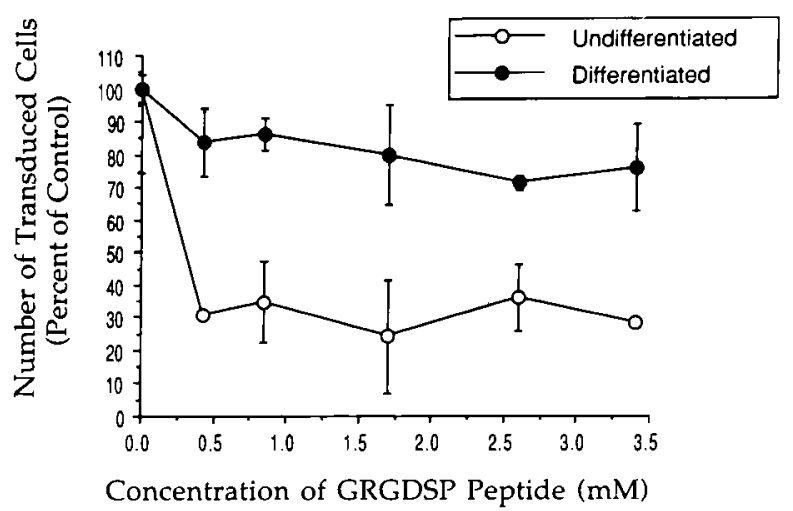

B

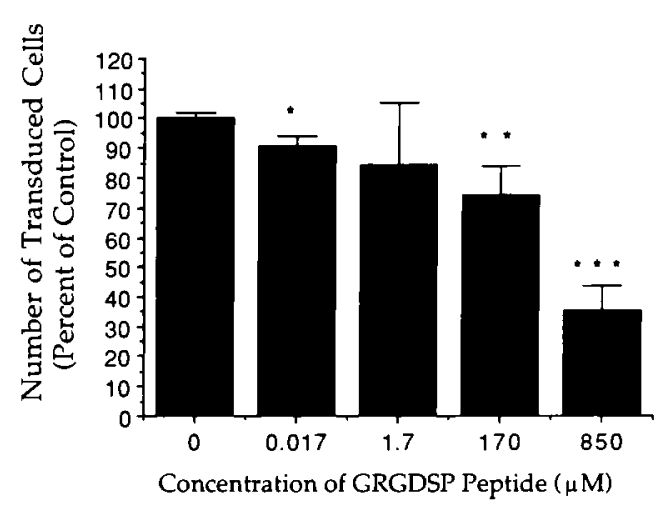

FIG. 2. A. Effect of GRGDSP peptide on transduction efficiency of AdRSVntlacZ in differentiated and undifferentiated Caco- 2 cells. Cells were pretreated with various concentrations of the peptide and binding occurred for $2 \mathrm{hr}$ at $4{ }^{\circ} \mathrm{C}$ to minimize degradation and cellular metabolism. Peptide was then removed and $50 \mathrm{lfu}$ of virus was added to the cells. Protocol for adenoviral infection and assay for lac $Z$ expression is described in Materials and Methods. B. Effect of low concentration GRGDSP peptide on the transduction efficiency of AdRSVntlacZ in undifferentiated Caco- 2 cells. In both panels, data are the result of three separate experiments and error bars represent the standard deviation of the data. ${ }^{*} p=0.02,{ }^{* *} p=0.01$, $* * * p<0.001$ (Student's $t$-test).

ported with $0.9 \mathrm{~m} M$ peptide, $75.8 \%$ seen with $1.7 \mathrm{~m} M, 64 \%$ with $2.6 \mathrm{mM}$, and $71.9 \%$ with $3.4 \mathrm{mM}$. When the peptide was added to the cells in micromolar concentrations, a more graduated, dose dependent response was seen (Fig. 2B). When 0.017 $\mu M$ of the peptide as added to the undifferentiated cells, a $9.5 \%$ reduction in transduction was seen ( $p=0.02$, Student's $t$-test). A concentration of $1.7 \mu M$ produced a $15.6 \%$ reduction and $170 \mu M$ produced a $25.7 \%$ reduction in transduction $(p=0.01)$.

Dramatic differences in blocking of adenoviral transduction between different levels of differentiation were not found in IEC-18 cells pre-treated with RGD peptide (Fig. 3 ). At a concentration of $0.9 \mathrm{mM}$ peptide, undifferentiated IEC-18 cells showed a $45.6 \%$ reduction in transduction of the lac $Z$ gene. Differentiated cells displayed a $37.5 \%$ reduction. The $1.7 \mathrm{~m} M$ concentration provided similar results. Additional inhibition of adenoviral transduction efficiency was seen at a concentration of 


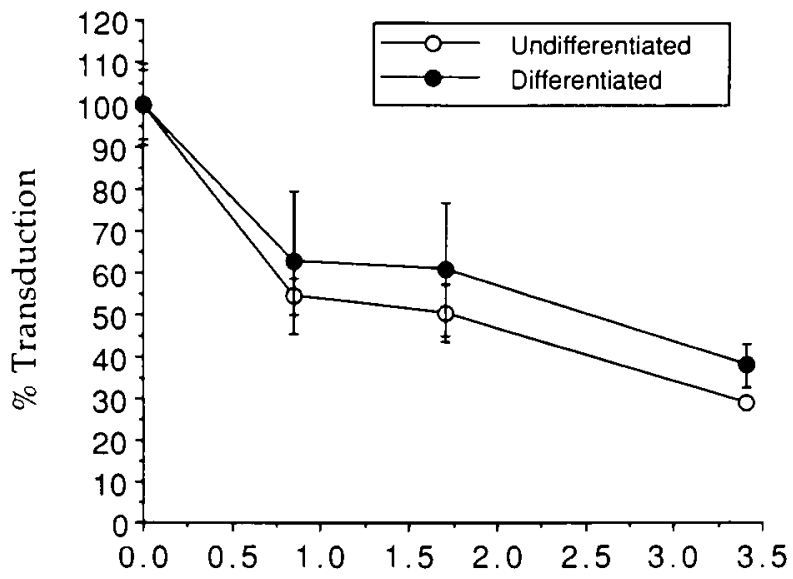

Concentration of GRGDSP Peptide (mM)

FIG. 3. Effect of GRGDSP peptide on adenoviral transduction efficiency in differentiated and undifferentiated IEC-18 cells. Methods of pretreatment with peptide and adenoviral infection were same as those for Caco- 2 cells. Data are the result of three separate experiments. Error bars represent the standard deviation of the data.

$3.4 \mathrm{~m} M$ peptide in both the differentiated and undifferentiated cells. Cells treated 3 days after seeding showed a $70.9 \%$ decrease in transduction efficiency and differentiated cells showed a drop of $61.7 \%$.

The RGD peptide specifically blocked integrin receptors responsible for adenoviral internalization on both of the intestinal cell lines studied. When the single aspartic acid residue was replaced by a glutamic acid residue, the new peptide at high concentration $(1.7 \mathrm{~m} M)$ was unable to affect adenoviral transduction significantly in both undifferentiated and differentiated IEC-18 and Caco-2 cells ( $p<0.01$, Student's $t$-test; Fig. 4).

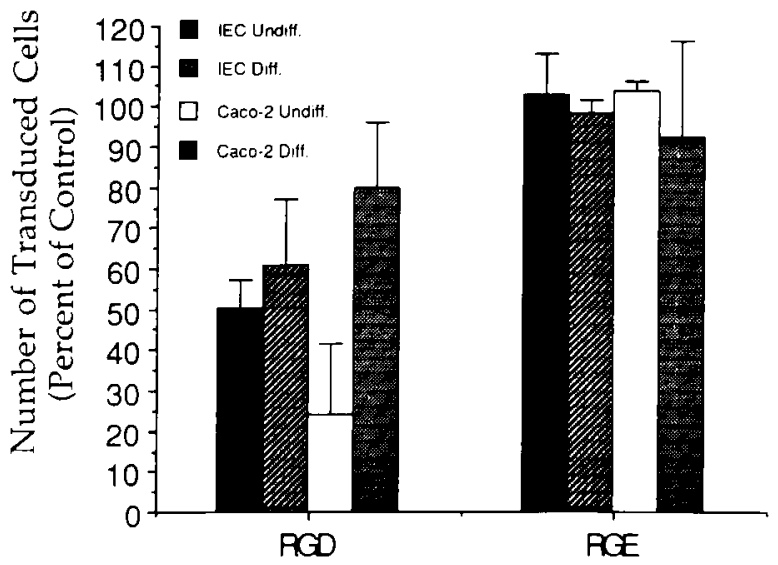

Peptide at $1.7 \mathrm{mM}$ Concentration

FIG. 4. Effect of GRGESP peptide on transduction efficiency of AdRSVntlacZ in differentiated and undifferentiated Caco-2 and IEC- 18 cells. Methods of pretreatment with peptide and adenoviral infection were same as those for the GRGDSP peptide studies. A concentrated solution of GRGESP peptide was unable to reduce adenoviral transduction significantly in both undifferentiated and differentiated IEC-18 and Caco- 2 cells $(p<0.01$, Student's $t$-test). Data are the result of two separate experiments and error bars represent the standard deviation of the data.

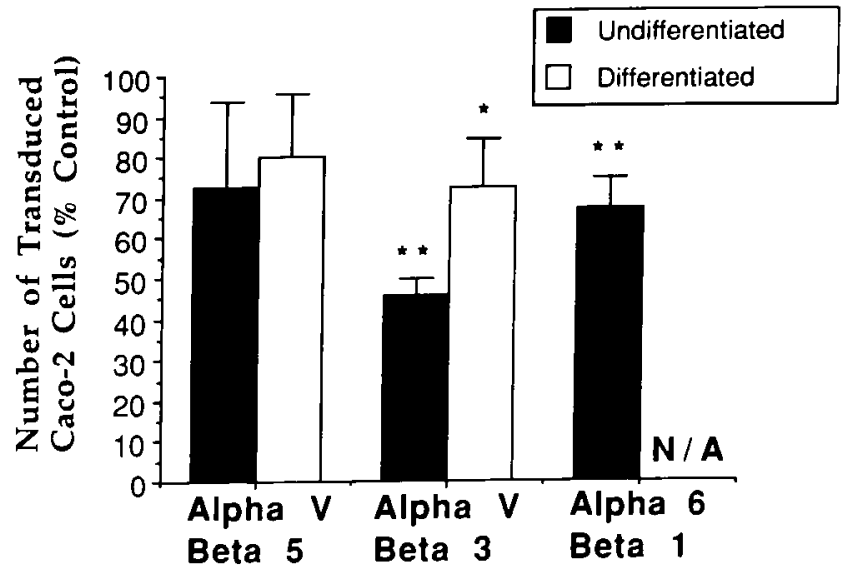

FIG. 5. Effect of anti-integrin antibodies on the ability of AdRSVntlacZ to transduce differentiated and undifferentiated Caco- 2 cells. Cells were pretreated with $1 \mu \mathrm{g} / \mu \mathrm{l}$ antibody for $2 \mathrm{hr}$ at $4^{\circ} \mathrm{C}$. A total of $50 \mathrm{lfu}$ of adenovirus was added and cells incubated at $4^{\circ} \mathrm{C}$ for $1 \mathrm{hr}$ to allow for viral binding. Cells were kept at $37^{\circ} \mathrm{C}$ for 30 min to allow for viral internalization. Unbound virus was removed by addition of trypsin and infection allowed to continue for $48 \mathrm{hr}$. Conservative calculations demonstrate that antibody concentration was in 1,000-fold excess of available receptors on the cell surface for all blocking experiments. Studies to screen for $\alpha_{6} \beta_{1}$ integrins were not performed in differentiated cells due to lack of response from other antiintegrin antibodies. Data are the result of two separate experiments and error bars represent the standard deviation of the data. ${ }^{*} p<0.001, * * p<0.0001$ (Student's $t$-test).

\section{Identification of specific integrins that influence} adenoviral transduction efficiency in the intestine

To identify integrins that play significant roles in adenoviral internalization in the intestine, Caco- 2 and IEC- 18 cells were

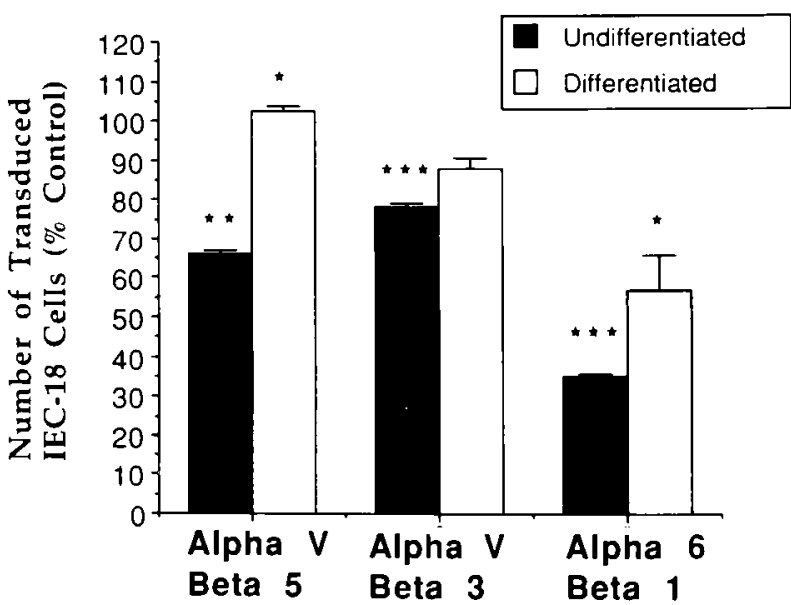

FIG. 6. Effect of anti-integrin antibodies on the ability of AdRSVntlacZ to transduce differentiated and undifferentiated IEC-18 cells. Methods of pretreatment with anti-integrin antibodies and adenoviral infection were same as those for Caco-2 cells. Results from differentiated cells treated with anti- $\alpha_{v} \beta_{3}$ integrin antibodies were not statistically significant due to a limited sample size. Other results are from three separate experiments and error bars represent the standard error of the mean of the data. ${ }^{*} p<0.01,{ }^{* *} p<0.001,{ }^{* * *} p<0.0001$ (Student's $t$-test) 

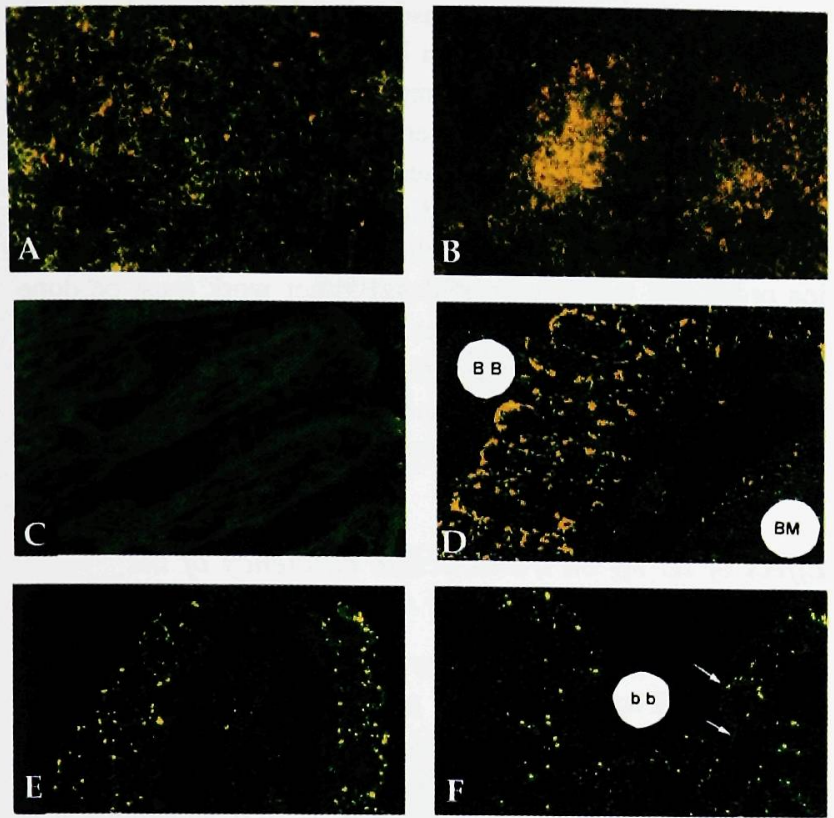

PLATE 1. Immunocytochemical localization of integrins in IEC-18 cells and intestinal segments of the Sprague-Dawley rat. Localization of $\alpha_{6} \beta_{1}$ integrins in undifferentiated (A) and differentiated (B) IEC-18 cells. Magnification, 150×. Integrins are located at cellular edges in both cases. In differentiated cells, areas of dome formation (yellow) are areas of intense integrin expression. IEC-18 cells expressed $\alpha_{\mathrm{v}} \beta_{5}$ integrins in a similar manner. $\alpha_{v} \beta_{3}$ integrins were not detected. C. Ileum control sample. No anti-integrin antibody added. Magnification, $100 \times$. D. Ileum $\alpha_{v} \beta_{5}$ integrins (yellow) are concentrated on the brush border (BB, brush border; BM, basement membrane). Similar staining patterns occurred with anti- $\alpha_{6} \beta_{1}$ integrin antibodies. Magnification, $65 \times$. E. Single villus from rat jejunum $\alpha_{v} \beta_{5}$ integrins are present, but are not as concentrated on the brush border as in the ileum. $\alpha_{v} \beta_{3}$ integrins were expressed in a similar manner. No $\alpha_{6} \beta_{1}$ integrins were identified in this segment. Magnification, $200 \times$. F. Colon $\alpha_{\mathrm{v}} \beta_{5}$ integrin expression is sparse with faint signals seen along the brush border (bb, white arrows). No additional integrin expression was seen in the colon. Yellow spots are areas of unspecific binding of secondary antibody to the tissue. Magnification, $100 \times$.

pretreated with anti-integrin antibodies prior to the addition of the adenovirus at early and late stages of differentiation. Significant differences in the blockade of adenoviral transduction were seen between differentiated and undifferentiated Caco-2 cells and between treatment with various antibodies (Fig. 5). When treated with antibody against $\alpha_{v} \beta_{5}$ integrins, undifferentiated cells showed a $27.5 \%$ drop in transduction efficiency and differentiated cells showed a $20 \%$ drop. When treated with antibody against $\alpha_{v} \beta_{3}$ integrin, undifferentiated cells showed a $54.3 \%$ reduction in adenoviral transduction (Student's $t$-test, $p<0.0001$ ) and differentiated cells showed a $27.8 \%$ drop (Student's $t$-test, $p<0.001$ ). Because differentiated cells were unresponsive to the blocking of integrins in previous studies, only undifferentiated Caco- 2 cells were treated with antibody against $\alpha_{6} \beta_{1}$. A $33 \%$ drop in transduction efficiency was seen when this integrin was blocked (Student's $t$-test, $p<0.0001$ ). Conservative calculations demonstrate that antibody concentration was in 1,000-fold excess of available receptors on the cell surface for all the described studies.
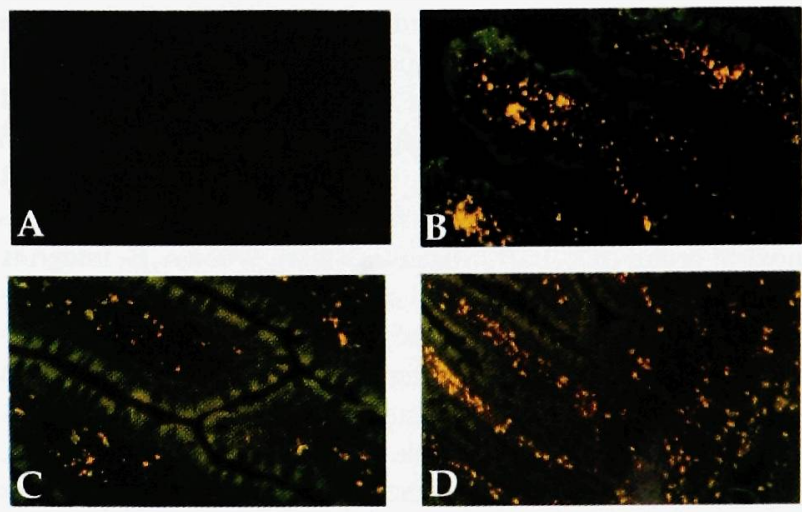

PLATE 2. Based on interrin expression, the ileum is a prime target for adenovirus-mediared gene transfer to the intestine. Segments of rat ileum and jejunum were ligated and adenovirus encoded with the jellyfish GFP at a concentration of $2 \times 10^{12}$ particles/ml was injected locally. Data were collected $24 \mathrm{hr}$ after infection. A. Little autofluorescence was detected in segments treated with a placebo dose of PBS. B. Ileal segments showed intense levels of transduction with gene expression seen throughout sections from the brush border side of the tissue. C. Gene expression is sparse in sections of jejunum treated with adenovirus. The photograph represents the only positive section obtained after screening sections that represented $50 \%$ of the treated tissue. D. Intense gene expression was seen in all parts of ileal sections including the basolateral side of the tissue. In all cases described here, the epithelial layer carries a distinct green fluorescence. Intense transgene expression (bright yellow) is also located in the lamina propria of the tissue samples. Magnification, $260 \times(A, B, D)$ and $400 \times(C)$.
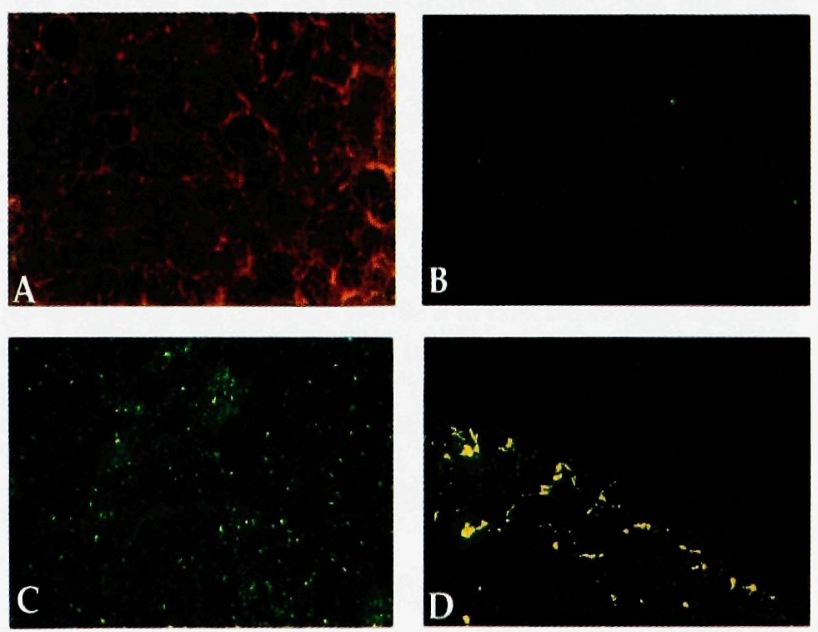

PLATE 3. Effect of inflammation on integrin expression in Caco- 2 cells and colonic tissue of the rat. A. Light micrograph

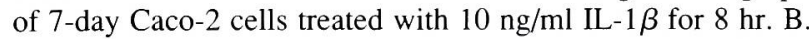
Immunocytochemical staining for $\alpha_{\mathrm{v}} \beta_{3}$ integrins on 7-day Caco- 2 cells not treated with IL-1 $\beta$. Similar results were seen for $\alpha_{\mathrm{v}} \beta_{5}$ integrins. C. Immunocytochemical localization of $\alpha_{\mathrm{v}} \beta_{3}$ integrins on Caco- 2 cells treated with $10 \mathrm{ng} / \mathrm{ml} \mathrm{IL-} 1 \beta$ for $8 \mathrm{hr}$. D. Immunohistochemical isolation of integrins in inflamed rat colonic tissue. Chronic intestinal inflammation was induced in adult female Lewis rats as decsribed in Materials and Methods. Twenty-one days after induction, during the chronic phase of inflammation, rats were sacrificed and colonic segments processed for immunohistochemical analysis. Untreated colonic tissue assessed for $\alpha_{v} \beta_{5}$ integrins can be seen in Plate $1 \mathrm{~F}$. Magnification, $200 \times(A-C)$ and $100 \times(D)$. 
The IEC-18 cell line showed results similar to those of the Caco- 2 cell line when $\alpha_{\mathrm{v}} \beta_{5}$ and $\alpha_{\mathrm{v}} \beta_{3}$ integrins were blocked (Fig. 6). When $\alpha_{\mathrm{v}} \beta_{5}$ integrins were blocked, undifferentiated cells demonstrated a $34 \%$ reduction in expression of the lacZ marker gene (Student's $t$-test, $p<0.001$ ). The differentiated cells showed no significant change in transduction of the adenoviral vector ( $p<0.01$, Student's $t$-test). When $\alpha_{\mathrm{v}} \beta_{3}$ integrins were blocked, undifferentiated cells demonstrated a $21.9 \%$ reduction in transduction efficiency of the virus $(p<0.0001$, Student's $t$-test), and the differentiated cells showed a $12.3 \%$ drop that was not determined to be statistically significant from control values due to limited sample size. In this particular cell line, $\alpha_{6} \beta_{1}$ integrins appear to have the most significant effect on adenoviral transduction efficiency. Undifferentiated cells showed a $65 \%$ reduction of lacZ expression $(p<0.0001$, Student's $t$ test) and differentiated cells demonstrated a $43.5 \%$ drop $(p<$ 0.01 , Student's $t$-test). These results correlate well with photographic data.

IEC-18 cells analyzed for $\alpha_{6} \beta_{a}$ integrin expression 3 days after seeding showed that there were numerous integrin receptors present and that they are concentrated at cellular edges (Plate 1A). Differentiated cells demonstrated similar expression patterns. Dome-like structures also stained heavily for the integrin (Plate 1B). A slightly lower expression pattern was seen for $\alpha_{\mathrm{v}} \beta_{5}$ integrins and little expression of $\alpha_{\mathrm{v}} \beta_{3}$ integrins was detected.

\section{Immunocytochemical localization of integrins in intestinal segments of the Sprague-Dawley rat}

To determine if the rat intestine expressed integrins associated with adenoviral internalization and which intestinal segment was best suited for adenovirus-mediated gene delivery, intestinal sections from rat ileum, jejunum, duodenum, and colon were isolated and treated with anti-integrin antibodies (Plate 1C-F). $\alpha_{\mathrm{v}} \beta_{5}$ integrins were highly concentrated on the brush border of the ileum as were $\alpha_{6} \beta_{1}$ integrins (Plate 1D). The jejunum showed some expression of $\alpha_{v} \beta_{3}$ integrins on the brush border, but not to the extent of that of the ileum. $\alpha_{\mathrm{v}} \beta_{5}$ integrins were expressed in a similar manner, but no expression of $\alpha_{6} \beta_{1}$ integrins was detected (Plate $1 \mathrm{E}$ ). Integrin expression in the colon was sparse. A thin line of $\alpha_{v} \beta_{5}$ integrin expression was seen along the brush border (white arrows, Plate $1 F$ ). No additional integrin expression was seen in the colon. The duodenum showed expression patterns similar to that of the colon.

\section{Infection of isolated intestinal loops of rat jejunum and ileum}

From the results reported above, we believe that, based on integrin expression, the ileum would be a prime target for efficient adenovirus-mediated gene delivery to the intestine. To prove this hypothesis, segments of rat ileum and jejunum (the target for gene expression in previous studies) were ligated and adenovirus encoding the jellyfish green fluorescent protein injected locally. All data was collected $24 \mathrm{hr}$ after infection. Little autofluorescence was associated with control samples treated with a saline bolus (Plate 2A). Ileal segments showed intense levels of transduction with gene expression seen throughout the sections from the brush border side of the tissue (Plate $2 \mathrm{~B}$ ) to the basolateral side (Plate 2D). When adenovirus was added to segments of the jejunum, transduction levels were low with sparse patches gene expression located in only a few sections of the treated tissue. Plate $2 \mathrm{C}$ represents the only positive section found after an initial screening of what represented $50 \%$ of the entire segment. In all cases described here, the epithelial layer carries a distinct green fluorescence. However, intense transgene expression (bright yellow) is also located in the lamina propria of the tissue samples. Further work must be done to identify the cell population transduced by the adenovirus in our samples as the lamina propria consists of a mixture of various cell types (fibroblasts, macrophages, lymphocytes, endothelial cells, etc.), many of which may be inhospitable to adenoviral transduction strategies.

\section{Effect of IL-1 $\beta$ on transduction efficiency of the adenovirus in differentiated $\mathrm{Caco}-2$ cells}

In an attempt to induce integrin expression in differentiated enterocytes, Caco- 2 cells were given various doses of $\Pi-1 \beta$ in a manner similar to that described previously (Dedhar, 1989; Hayward et al., 1995; Kitazawa et al., 1995). Eight hours after dosing, the cytokine was removed and 50 lfu of adenovirus was added to the cells for $48 \mathrm{hr}$. After this time, the number of transduced cells relative to the total cellular population was recorded (Fig. 7A). Results were significantly different from those obtained from untreated cells for all doses of $\amalg-1 \beta$ studied. When dosed with $0.001 \mathrm{ng} / \mathrm{ml} \mathrm{IL-1} \beta, 7.3 \%$ of the cellular population expressed the $l a c Z$ gene (Student's $t$-test, $p<0.01$ ), a value two times that of the untreated population. A dose of $1 \mathrm{ng} / \mathrm{ml}$ increased the transduced population to $9.9 \%$ (Student's $t$-test, $p<$ 0.01 ) and a dose of $10 \mathrm{ng} / \mathrm{ml}$ produced a transduction of $13.8 \%$, a value three times that of the control population (Student's $t$ test, $p<0.0001$ ).

Experiments in which differentiated Caco- 2 cells were dosed with $10 \mathrm{ng} / \mathrm{ml}$ of $\amalg-1 \beta$ and then treated with high concentrations of RGD peptide prior to viral infection, suggest that stimulation of integrin expression in response to the cytokine was responsible for the observed increase in adenoviral transduction in these cells (Fig. 7B). When $0.9 \mathrm{~m} M$ peptide was added to differentiated cells after an 8-hr treatment with $\mathrm{IL}-1 \beta$, transduction fell from $13.8 \%$ to $4.6 \%$, a value that is not statistically different from that seen in normal differentiated cells $(p=0.2$, Student's $t$-test). Additional evidence for increased integrin expression in response to the cytokine was obtained when inflamed Caco- 2 cells were treated with anti-integrin antibodies. A marked increase in expression of both $\alpha_{\mathrm{v}} \beta_{5}$ and $\alpha_{\mathrm{v}} \beta_{3}$ integrins was detected (Plate $3 C$ ). Similar effects were seen in sections of rat colon in which an inflammatory state was induced (Plate 3D). Untreated colonic tissue assessed for $\alpha_{v} \beta_{5}$ integrins can be seen in Plate $1 \mathrm{~F}$.

\section{DISCUSSION}

To explain inefficient adenovirus-mediated gene expression in the intestine in vivo, we have carefully studied adenoviral transduction efficiency after exposure to extreme changes in $\mathrm{pH}$, digestive enzymes, and bile salts in vitro (Walter et al., 1997a). These variables do not significantly alter adenoviral function. However, we found that transduction levels are quite 
A.
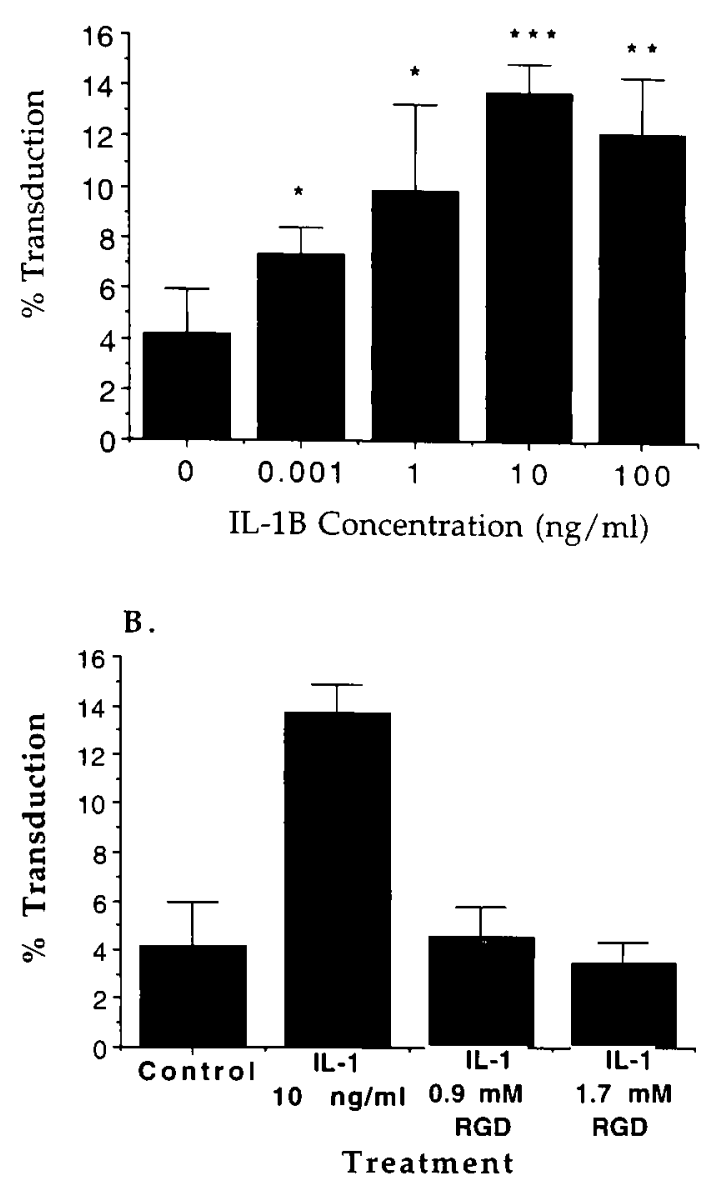

FIG. 7. IL-1 $\beta$ enhances adenoviral transduction in differentiated Caco- 2 cells. Cells were given various doses of IL- $1 \beta$ in serum-free medium. Eight hours after treatment, $50 \mathrm{lfu}$ of adenovirus was added to the cells and infection allowed to continue $48 \mathrm{hr}$. Data are the result of two separate experiments and error bars represent the standard deviation of the data. ${ }^{*} p<$ $0.01, * * p<0.001,{ }^{* * *} p<0.0001$ (Student's $t$-test). B. Infection inhibition studies with RGD peptide suggest that the observed increase of adenoviral transduction in differentiated enterocytes may be due to stimulation of integrin expression in response to IL- $1 \beta$. Cells were dosed with $10 \mathrm{ng} / \mathrm{ml} \mathbb{I L}-1 \beta$ for $8 \mathrm{hr}$ prior to treatment with the peptide. Adenovirus was added to the cells and infection continued for $48 \mathrm{hr}$. Data are the result of three separate experiments and error bars reflect the standard deviation of the data. Results from cells treated with the peptide were not statistically different from those of untreated cells $(p>0.05$, Student's $t$-test).

low in older, differentiated enterocytes in the absence of any physiological barriers. This effect has been reported in other cell types such as keratinocytes (Aneskievich et al., 1990) and airway epithelial cells (Dupuit $e$ t al., 1995), and in the intestine with other microbial pathogens such as Listeria monocytogenes (Gaillard and Finlay, 1996), Yersinia pseudotuberculosis (Coconnier et al., 1994), and simian immunodeficiency virus (Stone et al., 1995).

Distinct differences in adenoviral transduction efficiency were seen between the two cell lines studied (Fig. 1A). The in- testinal mucosa is composed of two populations of cells, the dividing, less specialized cells in the crypt (represented by IEC18 cells) and the mature, nondividing cells along the villus (Caco-2). The IEC-18 cell line is a primary cell line originating from the small intestine epithelium of the rat (Quaroni et $a l ., 1979)$. Even though these cells are from the rat and are said to represent undifferentiated crypt cells (Quaroni and Isselbacher, 1981), they do undergo moderate differentiation and express low levels of brush border enzymes similar to those of human enterocytes (Carroll et al., 1988). The Caco- 2 cell line, a human transformed cell line considered to be a standard model of the intestinal epithelium, shows high levels of differentiation and overexpression of brush border enzymes (Zweibaum et al., 1983; Yoshioka et al., 1991). In this report, electrical resistances were monitored to indicate when enterocyte monolayers have reached a differentiated state. Upon initial inspection of the data presented in Fig. 1, one may conclude that our reported decreases in adenoviral transduction efficiencies may simply be due to the fact that the cells have reached confluence and/or developed electrical resistances. It is important to note that transduction efficiency begins to drop as early as 3.5 days in culture and significant drops were detected only $12 \mathrm{hr}$ later. The cells were only $80-90 \%$ confluent between these time points and resistances were barely detectable. Integrins are involved in processes associated with differentiation such as cell adhesion (Stuiver et al., 1994), cell polarization, and tight junction formation (Eaton and Simons, 1995). Thus, different levels of integrin expression and distribution may be responsible for the differences in adenoviral transduction efficiency we have observed between these two cell types.

The role of integrins in the intestine is becoming a subject of increasing interest. Expression of $\alpha_{2} \beta_{1}$ and $\alpha_{3} \beta_{1}$ integrins has been detected in all cells of the small and large intestine along the crypt-villus axis (Choy et al., 1990). $\alpha_{6} \beta_{1}$ and $\alpha_{6} \beta_{4}$ interins were also found in adult human small intestine enterocytes (Beaulieu and Vachon, 1994). Some integrins play immunological roles in the intestine. The $\alpha_{7}$ family is associated with the gut-associated lymphoid tissue (Wagner et al., 1996) and the $\alpha_{4}$ family has been found to be the focus of attachment for T cells in Peyer's patches (Tsuzuki et al., 1996). Certain patterns of integrin receptor expression on normal and malignant colon epithelial cells have been associated with development and progression of large bowel cancer (Agrez, 1996). $\alpha_{v}$ integrins, those associated with adenoviral internalization, have not been identified in healthy human intestinal tissue to date (Gladson et al., 1994).

Studies involving the blockade of viral infection with the RGD peptide indicate that integrins which mediate adenoviral infection are present on both the Caco-2 and IEC-18 cell lines (Figs. 2 and 3). Transduction efficiencies in undifferentiated Caco- 2 cells were influenced by the presence of the peptide to a greater extent than in differentiated cells. As Caco- 2 cells differentiate, $\beta_{1}$ integrins redistribute from the cell surface to the basolateral membrane (Vachon et al., 1993; Coconnier et al., 1994). This re-location phenomena was exemplified in photographs of Caco- 2 cells treated with antibody against $\alpha_{\mathrm{v}} \beta_{5}$ integrins 3 and 21 days after seeding (Walter et al., 1997b). In undifferentiated cells, integrins were located around the edges of cells where there were no other cell contacts. In differentiated cells, areas of dome formation were the only site of inte- 
grin expression. In these areas, cells are raised from the growth substrate. Exposed integrins can then facilitate adenoviral internalization. A significant portion of gene expression was located on these domed areas of the highly differentiated monolayers.

Adenoviral transduction efficiencies in IEC-18 cells were not as sensitive to the RGD peptide between stages of differentiation. A reason for this can be drawn from results of immunocytochemical staining and infection inhibition studies with monoclonal antibodies. There were more $\alpha_{6} \beta_{1}$ integrin receptors present on the cellular surface of differentiated and undifferentiated cells than $\alpha_{v} \beta_{3}$ integrins (Plate lA,B). We found that the $\alpha_{6} \beta_{1}$ integrin also plays a significant role in adenoviral transduction in this cell line (Fig. 6), but does not utilize the RGD sequence in binding to laminin. This result may help explain why some adenoviral RGD mutants are not hindered from entering some cell types (Freimuth, 1996).

Continued growth of adherent cell lines potentially selects for variants best able to bind and spread on cultureware. The receptors responsible for this attachment are, by and large, members of the integrin family. Because growth in culture may favor excess expression of integrins, the usual localization properties of integrins become disrupted. Receptors that would normally be found exclusively localized on the basal surface of epithelial cells, and not found in contact with microorganisms, are now available for binding and internalization of viruses in culture. This raises the possibility that cultured cells may actually internalize viruses more efficiently than do host cells in vivo. This appears not to be the case, however, because strong correlations for integrin expression were found between our tissue samples and cell culture data. IEC-18 cells, originating from the ileum, have been reported to be useful models that faithfully reflect in vivo biological events (Napoli et al., 1991; Ma et al., 1992). These cells have high levels of $\alpha_{\mathrm{v}} \beta_{3}$ integrin expression, as does the ileum. Despite species differences, integrin expression in differentiated Caco- 2 cells was similar to that of the colon in vivo.

Because the ileum is very rich in integrin expression, we concluded that it should be considered as a prime target for adenovirus-mediated gene transfer in future studies. In vivo studies have confirmed this hypothesis. However, the in vivo data presented in this work raise considerable questions about the mechanism of adenoviral gene transfer in the intestine. We noted that while the epithelial layer expressed significant levels of the transgene $24 \mathrm{hr}$ after infection, highly concentrated areas of gene expression were located in the lamina propria. These results are somewhat contradictory to those reported by others in the literature where expression of the lac $Z$ gene was localized only in epithelial cells at the brush border and in intestinal crypt areas (Brown et al., 1997; Cheng et al., 1997). We believe that results obtained by these investigators are somewhast speculative due to the presence of high concentrations of microflora (and resultant high levels of endogenous gene expression) in the intestine-especially in the colon. For this reason, we selected the jellyfish GFP (Chalfie et al., 1994), a marker not present in any amount in the intestine, to study gene transfer to the ileum and jejunum of the rat.

Although the mechanism by which high levels of gene expression develop in the lamina propria is not firmly established by the experiments reported here, several general models can be discussed. Viruses can also migrate through paracellular spaces that lie between the enterocytes and inflammatory cells such as lymphocytes, eosinophils, and neutrophils are capable of using the paracellular pathway to transmigrate across the epithelium (Madara and Trier, 1994). Two possible mechanisms could be derived from these facts. First, tight junctions that would normally preclude viral particles from directly entering the lamina propria could be disrupted by our mechanical distention and ligation of the intestinal segments. Second, it is possible that during their trek across an enterocyte, scavenger cells such as monocytes and macrophages remove the virus from the enterocyte via phagocytosis. Transduction occurs and gene expression is seen once these cells reach the lamina propria. Identification of the cells expressing the transgene is currently underway in our laboratories.

Perhaps the most feasible explanation for the difference in transduction between the jejunum and the ileum as well as for concentration of the transgene in the lamina propria is that many pathogenic microorganisms exploit $M$ cells to cross the digestive epithelial barrier (Siebers and Finlay, 1996). M cells can transport soluble and particulate antigens across their cytoplasm via transcytosis and use this ability to sample lumenal antigens (Shanahan, 1994; Madara, 1997). These cells are located over subepithelial lymphoid follicles, Peyer's patches (Neutra et al., 1996), which are largest and most abundant in the ileum (Madara and Trier, 1994). Thus, the virus could enter the lamina propria by this route. This transport phenomena may be enhanced by an increase in viral intemalization due to the presence of the large number of integrins located on epithelial cells of the ileum and might be the reason for the high level of gene transfer observed in this area of the intestine when compared to the jejunum. If this is indeed the case, perhaps the intestine (especially the ileum) would be a better target for delivery of recombinant adenoviral vaccine vectors instead of delivery of transgenic proteins and peptides as we had originally planned.

Although the primary focus of this study was to determine the role integrins play in adenoviral transduction of differentiated and undifferentiated enterocytes and to correlate these results with in vivo events, it is important to note that other factors that influence adenoviral infection such as redistribution of the adenoviral fiber receptor could also influence viral transduction efficiency as cells differentiate. Further study of these factors is necessary to provide a complete picture of adenovirusmediated gene transduction in the intestine. However, we have shown that integrins do play a significant role in adenoviral infection of the intestinal epithelium both in vitro and in vivo. As enterocytes differentiate, integrin expression decreases. This coincides with significant reduction in adenoviral transduction efficiency. IEC-18 cells, representing intestinal stem cells, are rich in integrin expression and are easily transduced by the viral vector. Additional results suggest that, based on integrin expression, intestinal stem cells are logical targets for adenoviral gene transfer. However, access to these cells is somewhat limited by their location deep in the intestinal crypts and by a thick mucous layer that lines the epithelium. Data from infection inhibition studies with monoclonal antibodies suggest that $\alpha_{\mathrm{v}} \beta_{3}$ and $\alpha_{6} \beta_{1}$ integrins play the most significant role in adenoviral internalization in the intestine.

To deliver genes efficiently to highly differentiated cells, ways to up-regulate integrin expression prior to administration 
of the virus must be explored. In an effort to determine if the inflammatory process would influence adenoviral uptake and internalization, Caco- 2 cells were given various doses of IL$1 \beta$. This cytokine is also involved in the development of intestinal lesions associated with inflammatory bowel diseases, one of our therapeutic targets for adenovirus-mediated gene delivery to the intestine (Hoang et al., 1994). Significant increases in adenoviral transduction efficiency were seen as early as $8 \mathrm{hr}$ after a single dose was given (Fig. 7A). Experiments in which differentiated Caco-2 cells were dosed with $10 \mathrm{ng} / \mathrm{ml}$ of $\Pi-1 \beta$ and then treated with high concentrations of RGD peptide prior to viral infection, suggest that stimulation of integrin expression in response to the cytokine was responsible for the observed increase in adenoviral transduction in Caco-2 cells (Fig. 7B). Additional evidence for increased integrin expression in response to the cytokine was obtained when inflamed Caco-2 cells were treated with anti-integrin antibodies. A marked increase in expression of both $\alpha_{\mathrm{v}} \beta_{5}$ or $\alpha_{\mathrm{v}} \beta_{3}$ integrins was detected (Plate 3C) and similar effects were seen in sections of rat colon in which an inflammatory state was induced (Plate 3D). These results lead us to believe that, active inflammatory bowel disease may provide a favorable environment for efficient internalization of adenoviral vectors. Alternatively, pretreatment of the intestine with cytokines that up-regulate integrin expression may improve transduction efficiencies in vivo.

Another approach to enhance adenovirus-mediated gene delivery to the intestine would be to exploit methods of viral entry that do not depend on integrin expression. Adenovirus types 40 and 41 , viruses that are taken up with great efficiency in differentiated as well as undifferentiated enterocytes (Croyle $e t$ al., 1998), are missing RGD motifs in the penton base (Bai et al., 1993; Mathias et al., 1994). This suggests that these adenoviruses experience $\alpha_{\mathrm{v}}$-independent entry or interact with other cell surface molecules. Employment of these types of strategies may be the key to effective gene delivery to the intestinal epithelium.

\section{ACKNOWLEDGMENTS}

We gratefully acknowledge Raimund Kinne (Immunology Unit, University of Leipzig, Leipzig, Germany), Mike Imperiale (University of Michigan Department of Microbiology and Immunology), and John Hilfinger (TSRL Inc.) for insightful discussions regarding this work. We thank Ellen Zimmermann (University of Michigan Department of Internal Medicine) for providing inflamed colonic segments for immunohistochemical analysis and Kay Cherian (University of Michigan Vector Core) for initial assistance with the adenoviral vectors. We also thank Beverly Davidson and Richard Anderson (University of Iowa Gene Transfer Vector Core) for providing us with the adenoviral vector containing the jellyfish green fluorescent protein and Dianne Carr (St. James University, Leeds, UK), for assistance with immunohistochemistry. This work was supported by NIGMS grant GM 37188 .

\section{REFERENCES}

AGREZ, M.V. (1996). Cell adhesion molecules in colon cancer. Aust. N Z J. Surg. 66, 791-798.
ANESKIEVICH, B.J., LEE, J.I., and TAICHMAN, L.B. (1990). Analysis of adenovirus early and late gene expression in cultured epidermal keratinocytes. J. Invest. Dermatol. 94, 183-186.

ARTURSSON, P. (1991). Cell cultures as models for drug absorption across the intestinal mucosa. Crit. Rev. Ther. Drug Carrier Sys. 8, 305-330.

AUDUS, K.L., BARTEL, R.L., HILDALGO, I.J., and BORCHARDT, R.T. (1990). The use of cultured epithelial and endothelial cells for drug transport and metabolism studies. Pharmacol. Res. 7, 435-449.

BAI, M., HARFE, B., and FREIMUTH, P. (1993). Mutations that alter an Arg-Gly-Asp (RGD) sequence in the adenovirus type 2 penton base protein abolish its cell rounding activity and delay virus reproduction in flat cells. J. Virol. 67, 5198-5205.

BEAULIEU, J.F., and VACHON, P.H. (1994). Reciprocal expression of laminin-A chain isoforms along the crypt-villus axis in the human small intestine. Gastroenterology 106, 829-839.

BERGELSON, J.M., CUNNINGHAM, J.A., DROGUETT, G., KURTJONES, E.A., KRITHIVAS, A., HONG, J.S., HORWTTZ, M.S., CROWELL, R.L., and FINBERG, R.W. (1997). Isolation of a common receptor for Coxsackie B viruses and adenoviruses 2 and 5. Science 275, 1320-1323.

BROWN, G.R., THIELE, D.L., SILVA, M., and BEUTLER, B. (1997). Adenoviral vectors given intravenously to immunocompromised mice yield stable transduction of the colonic epithelium. Gastroenterology 112, 1586-1594.

CARROLL, K.M., WONG, T.T., DRABIK, D.L., and CHANG, E.B. (1988). Differentiation of rat small intestinal cells by extracellular matrix. Am. J. Physiol. 254 (Suppl.), G355-G360.

CHALFIE, M., TU, Y., EUSKIRCHEN, G., WARD, W.W., and PRASHER, D.C. (1994). Green fluorescent protein as a marker for gene expression. Science 263, 802-805.

CHANG, A.G., and WU, G.Y. (1994). Gene therapy: Applications to the treatment of gastrointestinal and liver diseases. Gastroenterology 106, 1076-1084.

CHENG, D.Y., KOLLS, J.K., LEI, D., and NOEL, R.A. (1997). In vivo and in vitro gene transfer and expression in rat intestinal epithelial cells by E1-deleted adenoviral vector. Hum. Gene Ther. 8, 755-765.

CHOY, M.Y., RICHMAN, P.I., HORTON, M.A., and MACDONALD, T.T. (1990). Expression of the VLA family of integrins in human intestine. J. Pathol. 160, 35-40.

COCONNIER, M.-H., BERNET-CAMARD, M.-F., and SERVIN, A.L. (1994). Host intestinal epithelial cell differentiation inhibits the cellentry of Yersinia pseudotuberculosis in colon carcinoma Caco-2 cell line in culture. Differentiation 58, 87-94.

COLLEDGE, W.H., RATCLIFF, R., FOSTER, D., WILLIAMSON, R., and EVANS, M.J. (1992). Cystic fibrosis mouse with intestinal obstruction. Lancet 340, 680.

CROYLE, M.A., ROESSLER, B.J., and AMIDON, G.L. (1998). In vitro and in vivo assessment of adenovirus 41 as a vector for gene delivery to the intestine. Gene Ther. (in press).

DEDHAR, S. (1989). Regulation of expression of the cell adhesion receptors, integrins by recombinant human interleukin-1 $\beta$ in human osteosarcoma cells: Inhibition of cell proliferation and stimulation of alkaline phosphatase activity. J. Cell. Physiol. 138, 291-299.

DEFER, C., BELIN, M.T., CAILLET-BOUDIN, M.L., and BOULANGER, P. (1990). Human adenovirus-host interactions: Comparative study with members of subgroups B and C. J. Virol. 64, 3661-3673.

DUPUIT, F., ZAHM, J.M., PIERROT, D., BREZILLON, S., BONNET, N., IMLER, J.L., PAVIRANI, A., and PUCHELLE, E. (1995). Regenerating cells in human airway surface epithelium represent preferential targets for recombinant adenovirus. Hum. Gene Ther. 6, 1185-1193.

EATON, S., and SIMONS, K. (1995). Apical, basal, and lateral cues for epithelial polarization. Cell 82, 5-8.

ENGELHARDT, J.F., YANG, Y., STRATFORD-PERRICAUDET, 
L.D., ALLEN, E.D., KOZARSKY, K., PERRICAUDET, M., YANKASKAS, J.R., and WILSON, J.M. (1993). Direct gene transfer of human CFTR into human bronchial epithelia of xenografts with E1-deleted adenoviruses. Nature Genet. 4, 27-34.

FREIMUTH, P. (1996). A human cell line selected for resistance to adenovirus infection has reduced levels of the virus receptor. J. Virol. 70, 4081-4085.

GAILLARD, J.L., and FINLAY, B.B. (1996). Effect of cell polarization and differentiation on entry of Listeria monocytogenes into the enterocyte-like Caco-2 cell line. Infect. Immun. 64, 1299-1308.

GLADSON, C.L., and CHERISH, D.A. (1994). The alpha V integrins. In Integrins: The Biological Problems. Y. Takada, ed. (CRC Press, Ann Arbor, MI) pp. 83-95.

GOLDMAN, M.J., and WILSON, J.M. (1995). Expression of $\alpha_{\mathrm{v}} \beta_{5}$ integrins is necessary for efficient adenovirus-mediated gene transfer in the human airway. J. Virol. 69, 5951-5958.

GRAHAM, F.L., and VAN DER EB, A.J. (1973). A new technique for the assay of infectivity of human adenovirus 5 DNA. Virology 52, 456-467.

GRASSET, E., PINTO, M., DUSSAUIX, E., ZWEIBAUM, A., and DESJEUX, J.F. (1984). Epithelial properties of human colonic carcinoma cell line Caco-2: Electrical parameters. Am. J. Physiol. 3(Pt. 1), C260-C267.

HAYWARD, I.P., WHITEHEAD, R.H., WARD, L., GIANELLO, R., DEMPSEY, P., BATES, R., and BURNS, G.F. (1995). Effect of TGF- $\beta$ on differentiated organoids of the colon carcinoma cell line LIM 1863. Immunol. Cell Biol. 73, 249-257.

HIDALGO, I.J., RAUB, T.J., and BORCHARDT, R.T. (1989). Characterization of the human colon carcinoma cell line (Caco-2) as a model system for intestinal epithelial permeability. Gastroenterology 96, 736-749.

HOANG, P., FLASSE, R., VAN HEUVERZWYN, R., and SIBILLE, C. (1994). Role of cytokines in inflammatory bowel disease. Acta Gastroenterol. Belg. 57, 219-222.

HRAPCHAK, R.J. (1987). Immunohistochemistry. In Theory and Practice of Histotechnology. D.C. Sheehan and B.B. Hrapchak, eds. (Battelle Press, Columbia, OH) pp. 310-326.

HUANG, S., ENDO, R.I., and NEMEROW, G.R. (1995). Upregulation of integrins $\alpha_{\mathrm{v}} \beta_{3}$ and $\alpha_{\mathrm{v}} \beta_{5}$ on human monocytes and T lymphocytes facilitates adenovirus-mediated gene delivery. J. Virol. 69, 2257-2263.

HUANG, S., KAMATA,T., TAKADA, Y., RUGGERI, Z.M., and NEMEROW, G.R. (1996), Adenovirus interaction with distinct integrins mediates separate events in cell entry and gene delivery to hemapoietic cells. J. Virol. 70, 4502-4508.

KITAZAWA, S., ROSS, F.P., MCHUGH, K., and TEITELBAUM, S.L. (1995). Interleukin 4 induces expression of the integrin $\alpha_{v} \beta_{3}$ via transactivation of the $\beta_{3}$ gene. J. Biol. Chem. 270, 4115-4120.

KOZARSKY, K.F., JOOSS, K., DONAHEE, M., STRAUSS, J.F.I., and WILSON, J.M. (1996). Effective treatment of familial hypercholesterolemia in the mouse model using adenovirus-mediated gene transfer of the VLDL receptor gene. Nature Genet. 13, 54-62.

LEDLEY, F.D. (1992). Somatic gene therapy in gastroenterology: Approaches and applications. J. Pediatr. Gastroenterol. Nutr. 14, 328-337.

MA, T.Y., HOLLANDER, D., BHALLIA, D., NGUYEN, H., and KRUGLIAK, P. (1992). IEC-18, a nontransformed small intestinal cell line for studying epithelial permeability. J. Lab. Clin. Med. 120, 329-341.

MADARA, J.L. (1997). The chameleon within: Improving antigen delivery. Science 277, 910-911.

MADARA, J.L., and TRIER, J.S. (1994). The functional morphology of the mucosa of the small intestine. In Physiology of the Gastrointestinal Tract. L.R. Johnson, ed. (Raven Press, New York) pp. 1577-1617.

MATHIAS, P., WICKHAM, T., MOORE, M., and NEMEROW, G.
(1994). Multiple adenovirus serotypes use $\alpha_{\mathrm{v}}$ integrins for infection. J. Virol. 68, 6811-6814.

MAYR, G.A., and FREIMUTH, P. (1997). A single locus on human chromosome 21 directs the expression of a receptor for adenovirus type 2 in mouse A9 cells. J. Virol. 71, 412-418.

MILLER, J.H. (1972). Behavior of mutants on indicator plates. In $E x-$ periments in Molecular Genetics. (Cold Spring Harbor Laboratory, Cold Spring Harbor, NY) p. 48.

NAPOLI, J.L., MARTIN, C.A., and HORST, R.L. (1991). Induction, inhibition, and analysis of vitamin D metabolism in cultured cells. Methods Enzymol. 206, 491-501.

NEUMANN, R., CHROBOCZEK, J., and JACROT, B. (1988). Determination of the nucleotide sequence for the penton-base gene of the human adenovirus type 5. Gene 69, 153-157.

NEUTRA, M.R., PRINGAULT, E., and KRAEHENBUHL, J.P. (1996). Antigen sampling across epithelial barriers and induction of mucosal immune responses. Annu. Rev. Immunol. 14, 275-300.

O'NEAL, W., HASTY, P., MCCRAY, P., JR., CASEY, B., RIVERAPEREZ, H., WELSH, M.J., BEAUDET, A.L., and BRADLEY, A. (1993). A severe phenotype in mice with a duplication of exon 3 in the cystic fibrosis locus. Hum. Mol. Genet. 2, 1561-1569.

QUARONI, A., and ISSELBACHER, K.J. (1981). Cytotoxic effects and metabolism of benzo[a]pyrene and 7,12-dimethylbenz[a]anthracene in duodenal and ileal epithelial cell cultures. J. Natl. Cancer Inst. 67, 1353-1362.

QUARONI, A., WANDS, J., TRELSTAD, R.L., and ISSELBACHER, K.J. (1979). Epithelioid cell cultures from rat small intestine: Characterization by morphologic and immunologic criteria. J. Cell Biol. 80, 248-265.

RAGOT, T., STRATFORD-PERRICAUDET, L.D., VINCENT, N., CHAFEY, P., VIGNE, E., GILGENKRANTZ, H., COUTON, D., BRIAND, P., KAPLAN, K.C., KAHN, A., and PERRICAUDET, M. (1994). Adenovirus-mediated transfer of a human dystrophan gene to skeletal muscle of mdx mouse. Gene Ther. 1, S53-S54.

ROESSLER, B.J., ALLEN, E.D., WILSON, J.M., HARTMAN, J.W., and DAVIDSON, B.L. (1993). Adenoviral-mediated gene transfer to rabbit synovium In Vivo. J. Clin. Invest. 92, 1085-1092.

SANDBERG, J.W., LAU, C., JACOMINO, M., FINEGOLD, M., and HENNING, S.J. (1994). Improving access to intestinal stem cells as a step toward intestinal gene transfer. Hum. Gene Ther. 5, 323-329.

SARTOR, R.B., COMARTIE, W.J., POWELL, D.W., and SCHWAB, J.H. (1985). Granulomatous enterocolitis induced in rats by purified bacterial cell wall fragments. Gastroenterology 89, 587-595.

SHANAHAN, F. (1994). The intestinal immune system. In L.R. Johnson, ed. Physiology of the Gastrointestinal Tract. (Raven Press, New York) pp. 643-684.

SIEBERS, A., and FINLAY, B.B. (1996). M cells and the pathogenesis of mucosal and systemic infections. Trends. Microbiol. 4, 22-29.

SMYTHE, W.R., HWANG, H.C., ELSHAMI, A.A., AMIN, K.M., ALBELDA, S.M., and KAlSER, L.R. (1995). Differential sensitivity of thoracic malignant tumors to adenovirus-mediated drug sensitization gene therapy. J. Thorac. Cardiovasc. Surg. 109, 626-631.

STEWART, P.L., and BURNETT, R.M. (1995). Adenovirus structure by $\mathrm{x}$-ray crystallography and electron microscopy. In The Molecular Repertoire of Adenovirus I. Virion Strucutre and Infection. W. Doerfler, and P. Bohm, eds. (Springer-Verlag, Berlin) pp. 25-38.

STONE, J.D., HEISE, C.C., CANFIELD, D.R., ELICES, M.J., and DANDEKAR, S. (1995). Differences in viral distribution and cell adhesion molecule expression in the intestinal tract of rhesus macaques infected with pathogenic and nonpathogenic SIV. J. Med. Primatol. 24, 132-140.

STUIVER, I., and O'TOOLE, T.E. (1994). Regulation of integrin function and cellular adhesion. Stem Cells 13, 250-262.

SWEETSER, D.A., HAUFT, S.M., HOPPE, P.C., BIRKENMEIER, E.H., and GORDON, J.I. (1988). Transgenic mice containing intestinal fatty-acid binding protein-human growth hormone fusion 
genes exhibit correct regional and cell-specific expression of the reporter gene in their small intestine. Proc. Natl. Acad. Sci. USA 85, 9611-9615.

THOMAS, M. (1991). The genetics and molecular biology of colorectal cancer. Curr. Opin. Oncol. 3, 702-710.

TOMKO, R.P., XU, R., and PHILIPSON, L. (1997). HCAR and MCAR: The human and mouse cellular receptors for subgroup $C$ adenovirus and group B coxsackieviruses. Proc. Natl. Acad. Sci. USA 94, 3352-3356.

TSUZUKI, Y., MIURA, S., SUEMATSU, M., KUROSE, I., SHIGEMATSU, T., KIMURA, H., HIGUCHI, H., SERIZAWA, H., YAGITA, H., OKUMURA, K., and ISHIL, H. (1996). $\alpha_{4}$ Integrin plays a critical role in early stages of $\mathrm{T}$ lymphocyte migration in Peyer's patches of rats. Int. Immunol. 8, 287-295.

VACHON, P.H., and BEAULIEU, J.-F. (1992). Transient mosaic patterns of morphological and functional differentiation in the Caco-2 cell line. Gastroenterology 103, 414-423.

VACHON, P.H., DURAND, J., and BEAULIEU, J.-F. (1993). Basement membrane formation and re-distribution of the $\beta_{1}$ integrins in a human intestinal co-culture system. Anat. Rec. 236, 567-576.

WAGNER, N., LOHLER, J., KUNKEL, E.J., LEY, K., LEUNG, E., KRISSANSEN, G., RAJEWSKY, K., and MULLER, W. (1996). Critical role for $\beta_{7}$ integrins in formation of the gut-associated lymphoid tissue. Nature 382, 366-370.

WALTER, E., CROYLE, M.A., DAVIDSON, B.L., ROESSLER, B.J., HILFINGER, J.M., and AMIDON, G.L. (1997a). Adenovirus mediated gene transfer to intestinal epithelial cells as a potential approach for oral delivery of peptides and proteins. J. Control Rel. 46, 75-87.

WALTER, E., CROYLE, M.A., ROESSLER, B.J., and AMIDON, G.L. (1997b). The absence of accessible vitronectin receptors in differentiated tissue may hinder adenoviral-mediated gene transfer to the intestinal epithelium. Pharmacol. Res. 14, 1216-1222.
WESTBROOK, C.A., CHMURA, S.J., ARENAS, R.B., KIM, S.Y., and OTTO, G. (1994). Human APC gene expression in rodent colonic epithelium in vivo using liposomal gene delivery. Hum. Mol. Genet. 3, 2005-2010.

WICKHAM, T.J., FILARDO, E.J., CHERESH, D.A., and NEMEROW, G.R. (1994). Integrin $\alpha_{v} \beta_{5}$ selectively promotes adenovirus mediated cell membrane permeabilization. J. Cell Biol. 127, 257-264.

YOSHIOKA, M., ERICKSON, R.H., MATSUMOTO, H., GUM, E., and KIM, Y.S. (1991). Expression of dipeptidyl aminopeptidase IV during enterocytic differentiation of human colon cancer (Caco-2) Cells. Int. J. Cancer 47, 916-921.

ZIMMERMANN, E.M., SARTOR, R.B., MCCALL R.D., PARDO, M., BENDER, D., and LUND, P.K. (1993). Insulinlike growth factor I and interleukin $1 \beta$ messenger RNA in a rat model of granulomatous enterocolitis and hepatitis. Gastroenterology 105, 399-409.

ZWEIBAUM, A., TRIADOU, N., KEDINGER, M., AUGERON, S., ROBINE-LEON, S., PINTO, M., ROUSSET, M., and HAFFEN, K. (1983). Sucrase-isomaltase: a marker of foetal and malignant epithelial cells of the human colon. Int. J. Cancer 32, 407-412.

Address reprint requests to: Dr. Maria A. Croyle University of Pennsylvania Wistar Institute Room 201 3601 Spruce St. Philadelphia, PA 19104

Received for publication July 7, 1997; accepted after revision December 17, 1997. 


\section{This article has been cited by:}

1. Yaw-Chong Tong, Shwu-Fen Chang, Chia-Yang Liu, Winston W.-Y. Kao, Chong Heng Huang, Jiahorng Liaw. 2007. Eye drop delivery of nano-polymeric micelle formulated genes with cornea-specific promoters. The Journal of Gene Medicine 9:11, 956-966. [CrossRef]

2. Filippos Kesisoglou, Phyllissa Schmiedlin-Ren, David Fleisher, Blake Roessler, Ellen M. Zimmermann. 2007. Restituting intestinal epithelial cells exhibit increased transducibility by adenoviral vectors. The Journal of Gene Medicine 8:12, 1379-1392. [CrossRef]

3. Phyllissa Schmiedlin-Ren, Filippos Kesisoglou, John A Mapili, Sayed E Sabek, Jeffrey L Barnett, William D Chey, Blake Roessler, Ellen M Zimmermann. 2005. Increased Transduction of Human Intestinal Epithelial Cells by Adenoviral Vectors in Inflammatory Bowel Disease. Inflammatory Bowel Diseases 11:5, 464-472. [CrossRef]

4. Nehal S. Parikh, Mark A. Currier, Yonatan Y. Mahller, Lisa C. Adams, Betsy Di Pasquale, Margaret H. Collins, Timothy P. Cripe. 2005. Oncolytic herpes simplex virus mutants are more efficacious than wild-type adenovirus Type 5 for the treatment of high-risk neuroblastomas in preclinical models. Pediatric Blood \& Cancer 44:5, 469-478. [CrossRef]

5. Shwu-Fen Chang, Han-Yi Chang, Yaw-Chong Tong, Sy-Hann Chen, Fei-Chin Hsaio, Shao-Chun Lu, Jiahorng Liaw . 2004. Nonionic Polymeric Micelles for Oral Gene Delivery In VivoNonionic Polymeric Micelles for Oral Gene Delivery In Vivo. Human Gene Therapy 15:5, 481-493. [Abstract] [PDF] [PDF Plus] 